\title{
Lysis of Vibrio cholerae Cells: Direct Isolation of the Outer Membrane from Whole Cells by Treatment with Urea
}

\author{
By ANURADHA LOHIA, ${ }^{1}$ ANADI N. CHATTERJEE ${ }^{2}$ \\ AND JYOTIRMOY DAS ${ }^{1 *}$ \\ ${ }^{1}$ Biophysics Division, Indian Institute of Chemical Biology, 4 Raja S. C. Mullick Road, \\ Calcutta 700 032, India \\ ${ }^{2}$ Research and Development Division, Organon (India) Ltd, 182 A. J. C. Bose Road, \\ Calcutta 700 014, India
}

(Received 28 October 1983; revised 6 March 1984)

\begin{abstract}
Cells of Vibrio cholerae underwent rapid autolysis when suspended in media of low osmolarity under non-growing conditions. Chaotropes like urea and guanidine. $\mathrm{HCl}$ which are potent protein denaturants caused complete and immediate lysis of whole cells. This unique sensitivity of $V$. cholerae to protein denaturants led to the development of a rapid method for the selective isolation of the outer membrane upon treatment of whole cells with urea. The composition of the outer membrane isolated from both whole cells and crude envelopes by treatment with urea was comparable with that of the outer membrane isolated by other conventional methods.
\end{abstract}

\section{INTRODUCTION}

Lysis of a bacterial cell generally results from damage to the peptidoglycan layer (Weibull, 1953). Autolysis occurs due to an uncontrolled action of endogenous peptidoglycan hydrolases or autolysins. In Gram-negative bacteria the peptidoglycan substrate is often inaccessible to the action of exogenously added hydrolases due to the existence of the outer membrane which acts as a diffusion barrier (Repaske, 1956; Weidel et al., 1960; Dirienzo et al., 1978). Mutants of Escherichia coli and Salmonella typhimurium altered in the organization of the outer membrane are more susceptible to the action of detergents and chelating agents (Yem \& Wu, 1978; Suzuki et al., 1978; Nikaido, 1979).

Studies on the cell envelope of Vibrio cholerae are of special interest since its enterotoxin is membrane-bound (Fernandes \& Bayer, 1977; Pearson \& Mekalanos, 1982) and is also released into the surrounding medium. However, until recently, little work had been carried out on the outer membrane proteins of $V$. cholerae (Sur \& Chatterjee, 1979; Kabir, 1980; Kelley \& Parker, 1981). Virtually no information is available on the sensitivity of these cells to membrane-active agents except for a preliminary report by Adhikari et al. (1969).

The present investigation was undertaken to study the inherent lytic properties of $V$. cholerae and its susceptibility to protein denaturants and to isolate the outer membrane directly from whole cells by treatment with urea.

\section{METHODS}

Bacteria and growth conditions. The bacterial strains used were Vibrio cholerae 569B (Serotype Inaba; hypertoxinogenic), Escherichia coli C600, E. coli JE5513 (Lpo), Salmonella typhimurium LT2 and S. typhimurium SL1 102 (Re). Vibrio cholerae was grown in medium containing $1 \%(w / v)$ Lab-Lemco powder (Oxoid), $1 \%(w / v)$ peptone (Difco) (pH 8.5) with 0.18 $\mathrm{M}-\mathrm{NaCl}$. All other strains were grown in the above medium (pH 7.2) supplemented with $0.09 \mathrm{~m}-\mathrm{NaCl}$. Cells were grown at $37^{\circ} \mathrm{C}$ on a gyratory shaker $(180-200$ r.p.m.) and bacterial growth was monitored by following the increase in culture turbidity at $\mathrm{OD}_{585}$. Strains $\mathrm{C} 600$ and JE5513 of E. coli, and S. typhimurium LT2 and SL1 102 were gifts from Dr J. T. Park, Tufts University, Boston, USA.

Lysis of whole cells. Routinely, a $2 \%$ inoculum of an overnight culture was added to fresh broth and cells were allowed to grow with shaking at $37^{\circ} \mathrm{C}$ for $120-180 \mathrm{~min}$, to yield $4-6 \times 10^{8} \mathrm{c}$.f.u. $\mathrm{ml}^{-1}\left(A_{585} 0 \cdot 6-0 \cdot 7\right)$. Cells were 
harvested by centrifugation at $10^{\circ} \mathrm{C}$ at $6000 \mathrm{~g}$ for $5 \mathrm{~min}$ and immediately resuspended in the appropriate buffer, at either $10^{\circ} \mathrm{C}$ or $37^{\circ} \mathrm{C}$. The volume was adjusted to maintain $5 \times 10^{8} \mathrm{c}$.f.u. $\mathrm{ml}^{-1}$. The tubes were incubated at different temperatures and lysis was monitored by the decrease in $\mathrm{OD}_{585}$.

Preparation of crude cell envelopes. The method of preparation of crude cell envelopes followed by separation of outer and inner membranes by sucrose density gradient centrifugation was essentially that of Schnaitman (1970), modified as noted below. Exponential phase cells (about $6 \times 10^{8}$ c.f.u. $\mathrm{ml}^{-1}$ ) of $V$. cholerae were harvested $(6000 \mathrm{~g}, 5 \mathrm{~min}$ ) and resuspended in $10 \mathrm{~mm}$-HEPES (Sigma, $\mathrm{pH} \mathrm{7-0)}$ containing $20 \%(\mathrm{w} / \mathrm{v})$ sucrose. The cells were disrupted in an MSE ultrasonic disintegrator until the $\mathrm{OD}_{585}$ of the suspension decreased by about $95 \%$. The cell lysate was treated with $100 \mu \mathrm{g}$ DNAase and RNAase $\mathrm{ml}^{-1}$ each (Sigma) for $10 \mathrm{~min}$. Intact cells were removed by low speed centrifugation and the cell lysate was diluted with two volumes of $10 \mathrm{mM}$-HEPES buffer and centrifuged for $60 \mathrm{~min}$ at $105000 \mathrm{~g}$ in a Sorvall AH 627 rotor. The pellet constituting the crude envelope fraction was either used as such or further purified after washing it once by centrifugation with HEPES buffer. All the above operations were carried out at $4^{\circ} \mathrm{C}$.

Isolation of outer membrane. (a) Sucrose density gradient centrifugation. The crude cell envelope was resuspended in $20 \%$ sucrose in $10 \mathrm{~mm}$-HEPES buffer. Approximately $1 \mathrm{ml}$ (about $10 \mathrm{mg}$ protein) of this suspension was layered onto an $18 \mathrm{ml}$ linear sucrose density gradient of $45-60 \%(\mathrm{w} / \mathrm{v})$ sucrose in $10 \mathrm{mM}$-HEPES (pH $7 \cdot 0$ ) with a $1 \mathrm{ml}$ cushion of $75 \%(\mathrm{w} / \mathrm{v})$ sucrose, and centrifuged at $4{ }^{\circ} \mathrm{C}$ for $9 \mathrm{~h}$ at $105000 \mathrm{~g}$ in a Sorvall $\mathrm{AH} 627$. The rest of the tube $(16 \mathrm{ml})$ was filled with $10 \mathrm{mM}-\mathrm{HEPES}$ buffer $(\mathrm{pH} \mathrm{7.0)}$. This modification was based on the short column gradient technique of Griffith (1978). Four distinct bands were visible which were collected by puncturing the tube at the bottom or by manual aspiration. The outer membrane was identified by its buoyant density in the gradient $\left(1.23 \mathrm{~g} \mathrm{ml}^{-1}\right)$ as the fourth band from the top. After collection, each of the four bands was diluted with $10 \mathrm{~mm}-$ HEPES ( $\mathrm{pH} \mathrm{7.0)}$ ) and pelleted by centrifugation at $105000 \mathrm{~g}$ for $30 \mathrm{~min}$ at $4{ }^{\circ} \mathrm{C}$. The pellets were washed once and resuspended in $10 \mathrm{~mm}$-HEPES buffer and stored at $-20^{\circ} \mathrm{C}$. Identical results were obtained when the more established method of sucrose density gradient centrifugation, using a linear sucrose gradient $(45-60 \%$, w/v) throughout the length of the tube and a longer running period of $24 \mathrm{~h}$ at $105000 \mathrm{~g}$, was used. The short column gradient technique was used in this investigation because of its convenience.

(b) Treatment with Sarkosyl NL97. Outer membrane proteins were isolated from the crude cell envelope after treatment with $0 \cdot 5 \%$ Sarkosyl NL97 (Geigy Industrial Chemicals, Ardsley, NY, USA) for 30 min at $24^{\circ} \mathrm{C}$ (Filip $e t$ al., 1973) followed by centrifugation at $105000 \mathrm{~g}$ for $60 \mathrm{~min}$. The pellet containing the outer membrane proteins was washed once with cold distilled water, resuspended in distilled water and stored at $-20^{\circ} \mathrm{C}$. The supernate was dialysed against distilled water for $24 \mathrm{~h}$ at $4^{\circ} \mathrm{C}$ and centrifuged at $105000 \mathrm{~g}$ for $60 \mathrm{~min}$. The pellet containing the inner membrane proteins was resuspended in cold distilled water and stored at $-20^{\circ} \mathrm{C}$.

Treatment with urea. Late exponential phase cells of $V$. cholerae $\left(6 \times 10^{10}\right.$ c.f.u. $\left.\mathrm{ml}^{-1}\right)$ were harvested and resuspended in $20 \mathrm{ml} 4 \mathrm{M}$-urea and incubated for $10 \mathrm{~min}$ at $24^{\circ} \mathrm{C}$, by which time more than $90 \%$ lysis had occurred, as judged by the decrease in $\mathrm{OD}_{585}$. The viscous lysate was thoroughly homogenized and the remaining unbroken cells were removed by two cycles of low speed centrifugation at $24^{\circ} \mathrm{C}$. The supernate was centrifuged at $105000 \mathrm{~g}$ for $60 \mathrm{~min}$ at $4^{\circ} \mathrm{C}$. The pellet was resuspended in a small volume of $10 \mathrm{~mm}$-HEPES buffer and incubated with $100 \mu \mathrm{g}$ DNAase and RNAase $\mathrm{ml}^{-1}$ each at $24^{\circ} \mathrm{C}$ for $30 \mathrm{~min}$. The resulting suspension was re-extracted with $4 \mathrm{M}-$ urea and centrifuged at $105000 \mathrm{~g}$ for $60 \mathrm{~min}$ at $4{ }^{\circ} \mathrm{C}$. The pellet was finally washed in cold distilled water and stored at $-20^{\circ} \mathrm{C}$ until use.

Crude cell envelopes were treated with $4 \mathrm{M}$-urea at $24^{\circ} \mathrm{C}$ for $10 \mathrm{~min}$ and centrifuged at $105000 \mathrm{~g}$ for $60 \mathrm{~min}$. The pellet was washed once with cold distilled water, resuspended in distilled water and stored at $-20^{\circ} \mathrm{C}$. The supernate was dialysed against water $\left(24 \mathrm{~h}, 4^{\circ} \mathrm{C}\right)$, centrifuged at $105000 \mathrm{~g}$ for $60 \mathrm{~min}$ at $4^{\circ} \mathrm{C}$ and the resulting pellet was resuspended in distilled water and stored at $-20^{\circ} \mathrm{C}$.

Analytical methods. Protein was measured by the method of Markwell et al. (1978) with bovine serum albumin as standard. LPS was isolated from crude cell envelope by $45 \%(w / v)$ aqueous phenol at $68^{\circ} \mathrm{C}$ (Westphal \& Jann, 1965). Total carbohydrate was estimated by phenol/sulphuric acid (Dubois et al., 1956) and heptose by cysteine/sulphuric acid (Wright \& Rebers, 1972). Phospholipids were extracted by chloroform/methanol/water (Bligh \& Dyer, 1959) and quantified from the lipid phosphate. Phosphate was measured by the method of Ames \& Dubin (1960). Phospholipids were identified by thin-layer chromatography on silica gel G plates (Merck) using the solvent chloroform/methanol/water $(65: 25: 4$, by vol.). The chromatogram was developed in iodine vapour.

Cytochrome $b_{1}$ was quantified from the oxidized - reduced difference spectra with sodium dithionite as the reducing agent and the value calculated from the $\varepsilon_{427}$ (Hager \& Deeb, 1967).

SDS-polyacrylamide gel electrophoresis. Proteins were analysed on a $10 \%$ SDS-polyacrylamide gel by the method of Laemmli (1970). The polysaccharide profile of purified LPS and the various outer membrane preparations was detected electrophoretically on a $5.6 \%$ SDS-polyacrylamide gel which was stained with periodic acid-Schiff's reagent (Jann et al., 1975; Stewart-Tull, 1965). Approximately $20 \mu \mathrm{g}$ total carbohydrate was loaded for each sample. A fixed current of $40 \mathrm{~mA}$ per slab was used for a run time of $6 \mathrm{~h}$ at $24^{\circ} \mathrm{C}$ for a $10 \mathrm{~cm}$ gel length.

Electron microscopy. Outer membrane preparations were negatively stained with $2 \%$ phosphotungstate (pH $7 \cdot 0)$ and examined under a JEOL $100 \mathrm{C}$ transmission electron microscope at $60 \mathrm{kV}$. 

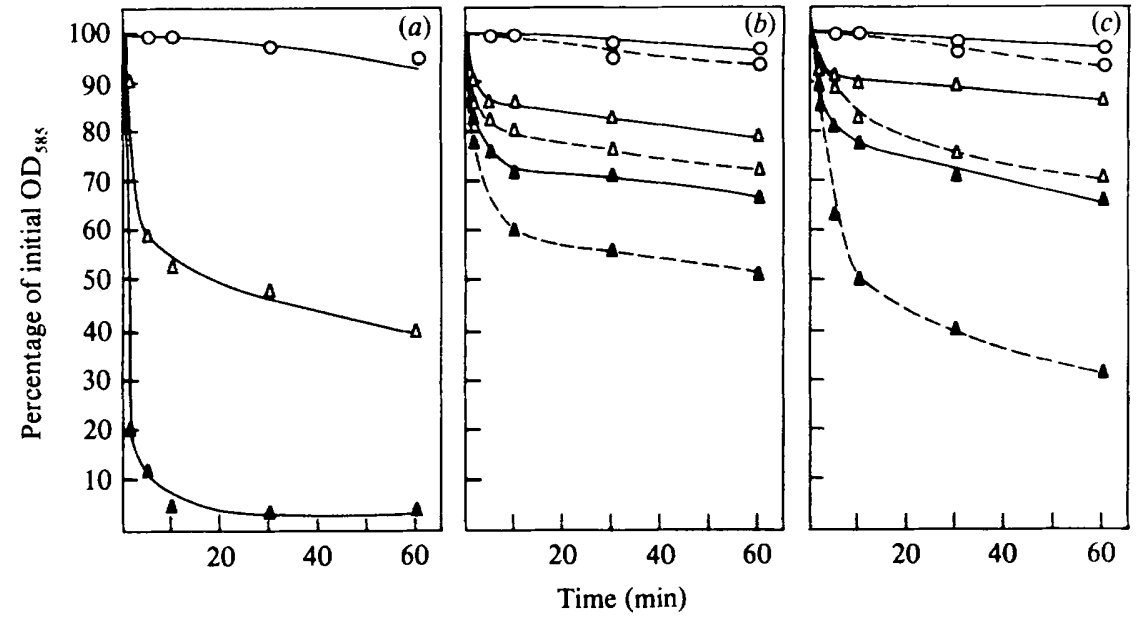

Fig. 1. Effect of urea on $V$. cholerae, $E$. coli and $S$. typhimurium. Exponential phase cells of $(a) V$. cholerae 569B, (b) E. coli (solid lines C609, broken lines JE5513), and (c) S. typhimurium (solid lines LT2, broken lines SL1102) were harvested and resuspended in: $50 \mathrm{~mm}$-phosphate buffer (pH 7.0) (O); 2 M-urea $(\triangle) ; 4$ M-urea $(\Delta)$. Lysis was monitored by the decrease in $\mathrm{OD}_{585}$.

\section{RESULTS}

Lysis of $V$. cholerae cells

$V$. cholerae cells harvested in the exponential phase of growth lysed rapidly when suspended in a hypotonic medium. Relatively little increment in lysis was observed with addition of EDTA and Tris $/ \mathrm{HCl}$. With increasing concentrations of Tris/ $\mathrm{HCl}$ and $\mathrm{NaCl}$ the rate of cellular lysis decreased progressively. Stationary phase cells exhibited a similar effect except that the rate of lysis was slower.

\section{Effect of urea and other protein denaturants}

Cells of the different bacterial strains harvested in the late exponential phase of growth were suspended in water containing urea $(2 \mathrm{M}$ and $4 \mathrm{M})$ and incubated at $24^{\circ} \mathrm{C}$. Figure 1 shows that $4 \mathrm{M}$-urea caused instantaneous lysis of $V$. cholerae cells, the $\mathrm{OD}_{585}$ of the suspension decreasing by more than $85 \%$ in $5 \mathrm{~min}$. A further increase in the concentration of urea did not affect the degree of lysis. Similar lytic effects could be seen with other protein denaturants like $6 \mathrm{M}$ guanidine. $\mathrm{HCl}$ and $6 \mathrm{M}$-ammonium thiocyanate. No detectable lysis was observed if heattreated cells of $V$. cholerae $\left(100^{\circ} \mathrm{C}, 5 \mathrm{~min}\right)$ were treated with urea. Different strains of $E$. coli and $S$. typhimurium were also used to compare the effect of urea on well characterized strains having defined lesions in their outer membrane. The effect of urea was significantly lower on whole cells of $E$. coli C600 and S. typhimurium LT2 (Fig. $1 b, c$ ), both of which are known to have a normal complement of cell envelope components. Response of the mutant strains, one deficient in the lipoprotein ( $E$. coli JE5513) and the other ( $S$. typhimurium SL1102) with a 'deep rough' LPS, to urea was relatively more, but still much less, than that seen with $V$. cholerae 569B (Fig. $1 a$ ). These mutant strains have been shown to be more sensitive to lysis by exogenous agents such as EDTA and detergents (Suzuki et al., 1978; Nikaido, 1979).

\section{Characterization of the insoluble residue isolated after lysis of cells by $4 \mathrm{M}-$ urea}

The composition of the cellular components resistant to solubilization by urea was compared with the crude cell envelope and outer membrane preparations isolated by established techniques such as sucrose density gradient centrifugation and detergent extraction of the crude envelope. The urea-insoluble material was isolated from both whole cells and crude envelope.

Proteins. The protein profiles of the urea-insoluble residue isolated from whole cells (Fig. 2, lane C) or crude envelope (lane G) were identical and matched the outer membrane protein profile isolated by Sarkosyl treatment of crude envelope (lane F). On the other hand, the protein 


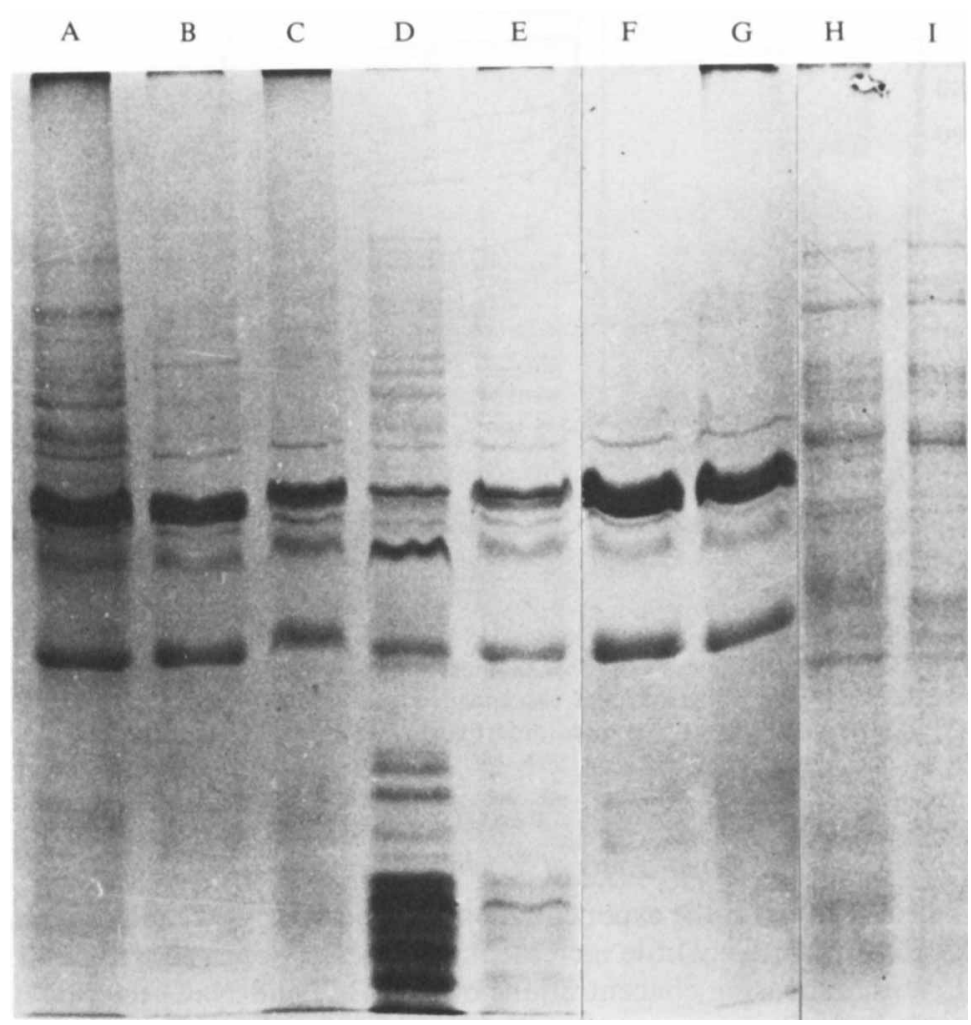

Fig. 2. SDS-polyacrylamide gel electrophoresis of $V$. cholerae 569B membrane proteins. Lane A, protein profile of $V$. cholerae 569B crude cell envelope; lane B, outer membrane isolated after density gradient centrifugation; lane $C$, urea-insoluble residue from whole cells; lane $D$, residue after lysis of cells in distilled water; lane $\mathrm{E}$, residue after lysis of cells in Tris/ $\mathrm{HCl}$ and EDTA; lane $\mathrm{F}$, outer membrane proteins isolated by treatment of crude envelope with Sarkosyl; lane $G$, urea-insoluble residue isolated from crude envelope; lane H, Sarkosyl-extracted inner membrane proteins; lane I, urea-soluble proteins from crude envelope.

profiles of residues obtained after lysis of whole cells in distilled water alone (lane D) or by Tris/ $\mathrm{HCl}$ and EDTA (lane E) were not comparable to either outer membrane (lane F) or crude envelope proteins (lane A). Sucrose density gradient centrifugation of the crude envelope yielded four well separated bands. The protein profile of the fourth band from the top of the gradient, whose buoyant density matches that of the outer membrane of other enteric bacteria (Lugtenberg \& Van Alphen, 1983), is shown in Fig. 2, lane B. This was identical to the protein profile of the crude envelope (lane A), suggesting incomplete separation of the two membranes by this technique. The protein profiles of the other three bands were found to be similar to that of the fourth band. In contrast, treatment of crude envelopes by Sarkosyl resulted in distinct inner and outer membrane protein profiles (Fig. 2, lanes $\mathrm{H}$ and $\mathrm{F}$, respectively).

LPS and phospholipids. Two species of phospholipids, phosphatidylethanolamine and phosphatidylglycerol, could be detected in the chloroform/methanol extract of the urea-insoluble residue. SDS-PAGE of the urea-insoluble residue revealed two periodic acid-Schiff-positive bands which had the same mobility as purified LPS (distance travelled from the origin -6.5 and $8.5 \mathrm{~cm}$ ). Since KDO (2-keto-3-deoxyoctonate) is not present in the LPS of $V$. cholerae (Raziuddin \& Kawasaki, 1976) the ratio of heptose to total carbohydrate was measured in the urea-insoluble residue and found to be identical to that obtained with purified LPS $(1: 2 \cdot 7)$. The total yield of the urea-insoluble residue isolated from whole cells or crude envelope was similar to the Sarkosyl-extracted outer membrane and was about half that of the crude envelope (Table 1). The 
Table 1. Total yield and composition of different membrane preparations

Values given indicate the range obtained with three different sets of membrane preparations.

\section{Membrane preparation}

Crude cell envelope

Sarkosyl-extracted outer membrane

Urea-insoluble residue isolated from whole cells or crude envelope

\section{Percentage of cell dry wt}

$20-26$

9.6-10

$9 \cdot 8-12$

\section{Protein*}

Phospholipid*†

$$
\begin{gathered}
31-39 \\
5-6
\end{gathered}
$$$$
13-15
$$

\section{LPS*}

$16-18$

$18-20$

* Expressed as percentage dry weight of the preparation.

† Total phospholipids were quantified by multiplying the amount of extractable lipid phosphate by 700 , which was taken to be the average molecular weight of phospholipids.

$\ddagger$ LPS was quantified by determining the heptose content of the various membrane preparations and from the known amount of heptose present in purified LPS isolated from crude cell envelopes.
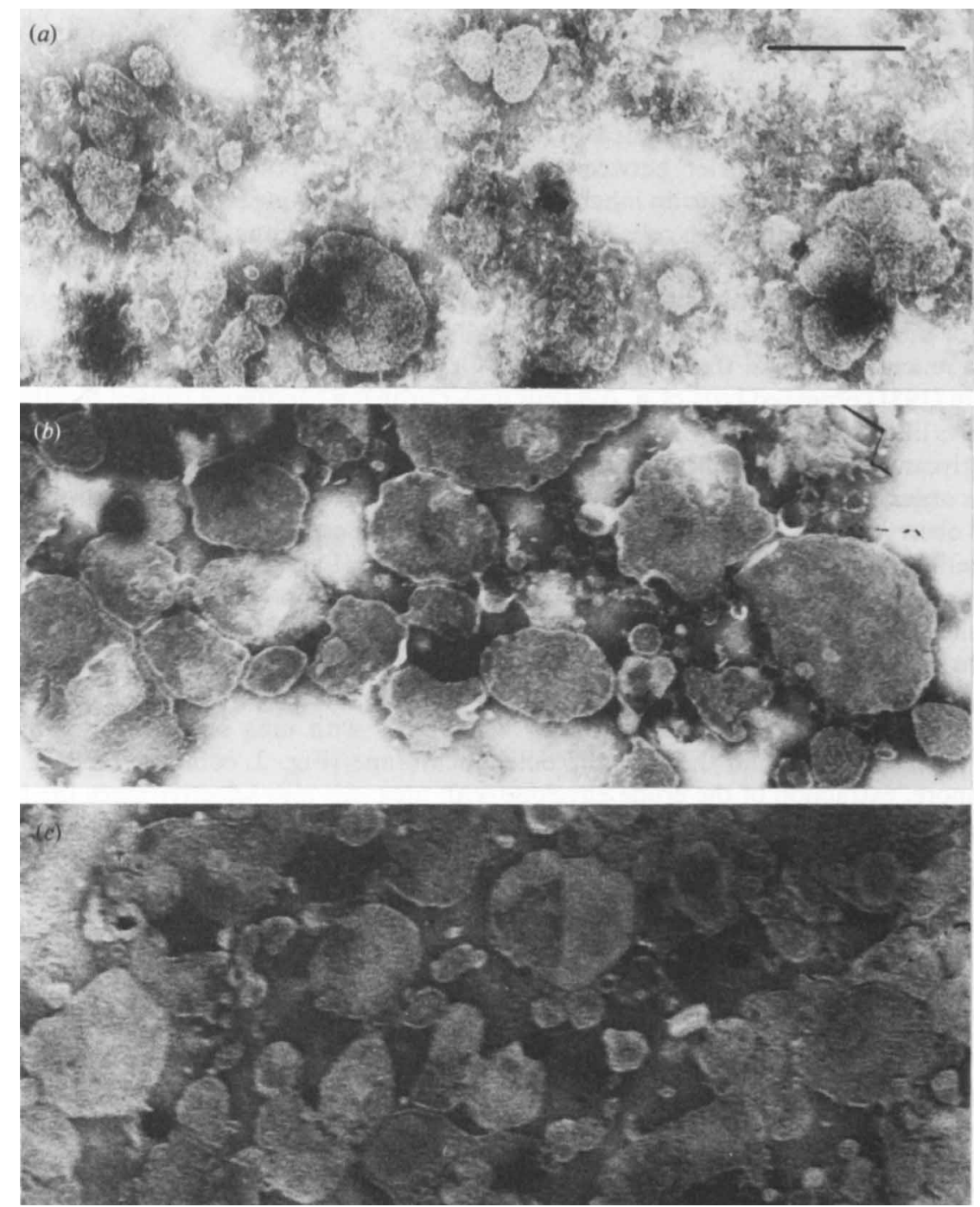

Fig. 3. Electron micrographs of negatively stained outer membrane preparations from $V$. cholerae 569B. Outer membranes isolated by $(a)$ sucrose density gradient centrifugation, $(b)$ treatment of crude envelope with urea, $(c)$ treatment of crude envelope with Sarkosyl, and stained with $2 \%$ phosphotungstate. Bar represents $0.2 \mu \mathrm{m}$. 
LPS present in the crude envelope was quantitatively recovered in the urea-insoluble residue and Sarkosyl-extracted outer membrane. About $30 \%$ of the total phospholipids present in the crude cell envelope was recovered in the urea-insoluble residue. As one would expect, the detergent-extracted outer membrane had a low content of phospholipids.

Cytochrome content. Cytochrome $b_{1}$, which is a characteristic constituent of the inner membrane, was assayed in all the outer membrane preparations to determine the extent of contamination by inner membrane constituents. The relative distribution of cytochrome $b_{1}$ in crude cell envelope, density gradient-separated outer membrane, urea-insoluble residue and Sarkosyl-extracted outer membrane was $100: 46: 20: 0$. Since the protein profile of the ureainsoluble residue did not reveal any detectable contamination by inner membrane proteins, it is possible that such a presence of cytochrome $b_{1}$ may be due to a specific association which can only be removed by strong detergent treatment (Horio et al., 1960).

Electron microscopy. Negatively stained electron micrographs of outer membranes prepared by sucrose density gradient centrifugation and by Sarkosyl or urea treatment of crude envelopes are shown in Fig. 3.

\section{DISCUSSION}

Lysis of $V$. cholerae cells suspended in low osmolarity medium could be due either to the absence of the putative 'barrier' between autolysins and the peptidoglycan as suggested for $E$. coli (Hartmann et al., 1974) or to an inherently fragile cell supporting structure. The fact that this lysis is slower at $10^{\circ} \mathrm{C}$ and with cells harvested in the stationary phase of growth suggests that autolytic enzymes may also be involved. However, it is also possible that the peptidoglycan network in $V$. cholerae is inherently fragile. It may be relevant to note that the peptidoglycan content of the related species $V$. fetus is around $0 \cdot 2-0 \cdot 26 \%$ (dry weight) (Winter et al., 1971), which is much lower than that found in other Gram-negative bacteria (Ghuysen, 1968).

Ingram (1981) observed lysis of $E$. coli cells under growing conditions caused by ethanol and chaotropes like urea and thiocynate. He proposed an alteration in the membrane association of peptidoglycan cross-linking enzymes as the possible basis of such lysis. This is clearly different from our observation where non-growing cells were lysed by urea and other chaotropes. Earlier workers observed lysis of halobacteria by urea and hypothesized that the cell envelopes were held together by predominantly non-covalent interactions (Larsen, 1967). Lysis of $V$. cholerae cells by protein denaturants indicated the importance of non-covalent interactions in the maintenance of cellular integrity. Although extensive lysis of whole cells was observed upon resuspension in distilled water or Tris/ $\mathrm{HCl}$ buffer $(\mathrm{pH} \mathrm{8.0)}$ containing EDTA, the protein profile of the residues isolated after lysis clearly indicated that they were associated with cytoplasmic proteins. In contrast, extraction of whole cells with urea selectively solubilized all cellular proteins other than those of the outer membrane (Fig. 2, compare lanes $\mathrm{C}$ and F). Furthermore, extraction of the crude envelope with urea was also selective since the insoluble residue contained the outer membrane proteins (lane $G$ ) while the soluble material contained the inner membrane proteins (Fig. 2, compare lanes $\mathbf{H}$ and I). A clean separation of the outer and inner membranes of $V$. cholerae was not achieved by the sucrose density gradient centrifugation. Interestingly, Kelley \& Parker (1981) also failed to separate the two membrane systems cleanly by this technique and proposed that the secretory behaviour of this organism might result in linking the inner and outer membranes more tightly than in other Gram-negative bacteria. The other widely used technique for separating the two membrane systems is based on selective solubilization by detergents, but one of the principal disadvantages in the use of detergents is the loss of phospholipids from such outer membrane preparations (Lugtenberg \& Van Alphen, 1983). Our method of isolation of outer membrane with its full complement of phospholipids, proteins and LPS may be applicable to other Gram-negative bacteria which display similar susceptibility to lysis.

This work was supported by the Council of Scientific and Industrial Research and the Department of Science and Technology [grant no. 11(35)/78-SERC], Government of India. We are grateful to Dr S. Mazumdar and Mr S. N. Dey for helping us with electron microscopy. 


\section{REFERENCES}

Adhikari, P. C., Raychaudhuri, C. \& Chatterjee, S. N. (1969). The lysis of cholera and El Tor vibrios. Journal of General Microbiology 59, 91-95.

Ames, B. N. \& Dubin, T. (1960). The role of polyamines in the neutralisation of bacteriophage deoxyribonucleic acid. Journal of Biological Chemistry 235, 769-775.

Bligh, G. G. \& DYer, W. J. (1959). A rapid method of total lipid extraction and purification. Canadian Journal of Biochemistry and Physiology 37, 911-917.

Dirienzo, J. M., Nakamura, K. \& INouYe, M. (1978). The outer membrane proteins of Gram-negative bacteria. Biosynthesis, assembly and functions. Annual Review of Biochemistry 47, 481-532.

Dubois, M., Gilles, K. A., Hamilton, J. K., Rebers, P. A. \& SMITH, F. (1956). Colorimetric method for determination of sugars and related substances. Analytical Chemistry 28, 350-356.

Fernandes, P. B. \& BAYER, M. E. (1977). Membranebound enterotoxin of Vibrio cholerae. Journal of General Microbiology 103, 381-387.

Filip, C., Fletcher, G., Wulf, J. L. \& Earhart, C. F. (1973). Solubilisation of the cytoplasmic membrane of Escherichia coli by the ionic detergent sodium lauryl sarcosinate. Journal of Bacteriology 115, 717-722.

GHUYSEN, J. M. (1968). Use of bacteriolytic enzymes in determination of wall structure and their role in cell metabolism. Bacteriological Reviews 32, 425-464.

GrIfFITH, O. M. (1978). Rapid density gradient centrifugation using short column techniques. Analytical Biochemistry 90, 435-443.

HAGER, L. P. \& DEEB, S. S. (1967). The preparation of bacterial cytochrome $b_{1}$. Methods in Enzymology 10 , 367-372.

Hartmann, R., Bock-Hennig, S. B. \& Schwarz, U. (1974). Murein hydrolases in the envelope of Escherichia coli. Properties in situ and solubilisation from the envelope. European Journal of Biochemistry 41, 203-208.

Horio, T., Higashi, T., Sasagarwa, M., Kusai, K., Nakai, M. \& OKanuKi, K. (1960). Preparation of crystalline Pseudomonas cytochrome C-551 and its general properties. Biochemical Journal 77, 194 201.

INGRAM, L. O. (1981). Mechanism of lysis of Escherichia coli by ethanol and other chaotropic agents. Journal of Bacteriology 146, 331-336.

JANN, B., RESKE, K. \& JANN, K. (1975). Heterogeneity of lipopolysaccharides. Analysis of polysaccharide chain lengths by sodium dodecyl sulphate-polyacrylamide gel electrophoresis. European Journal of Biochemistry 60, 239-246.

KABIR, S. (1980). Composition and immunochemical properties of outer membrane proteins of Vibrio cholerae. Journal of Bacteriology 144, 382-389.

Kelley, J. T. \& PARKeR, C. D. (1981). Identification and preliminary characterisation of Vibrio cholerae outer membrane proteins. Journal of Bacteriology 145, 1018-1024.

LAEMMLI, U. K. (1970). Cleavage of structural proteins during the assembly of the head of bacteriophage $\mathrm{T} 4$. Nature, London 227, 680-685.

LARSEN, H. (1967). Biochemical aspects of extreme halophilism. Advances in Microbial Physiology 1, 97132.

LUGTENBerg, B. \& VAN Alphen, L. (1983). Molecular architecture and functioning of the outer membrane of Escherichia coli and other Gram-negative bacteria. Biochimica et biophysica acta 737, 51-115.

Markwell, M. A. K., HaAs, S. M., Bieber, L. L. \& TOLBERT, N. E. (1978). A modification of the Lowry procedure to simplify protein determination in membrane and lipoprotein samples. Analytical Biochemistry 87, 206-210.

NikaIDO, H. (1979). Non specific transport through the outer membrane. In Bacterial Outer Membranes, pp. 361-407. Edited by M. Inouye. New York: John Wiley \& Sons.

Pearson, G. D. N. \& Mekalanos, J. J. (1982). Molecular cloning of Vibrio cholerae enterotoxin genes in Escherichia coli $\mathrm{K}-12$. Proceedings of the National Academy of Sciences of the United States of America 79, 2976-2980.

Raziuddin, S. \& Kawasaki, T. (1976). Biochemical studies on the cell wall lipopolysaccharides (O-Antigens) of Vibrio cholerae 569B (Inaba) and El Tor (Inaba). Biochimica et biophysica acta 431, 116-126.

REPASKE, R. (1956). Lysis of Gram-negative bacteria by lysozyme. Biochimica et biophysica acta 22, 189191.

Schnatman, C. A. (1970). Protein composition of the cell wall and cytoplasmic membrane of Escherichia coli. Journal of Bacteriology 104, 890-901.

Stewart-Tull, D. E. S. (1965). A modified PAS staining technique for polysaccharides in gels. Immunology 8, 221-222.

Sur, P. \& Chatterjee, S. N. (1979). Molecular weight and analysis of protein units in Vibrio cholerae cell envelope. Journal of General and Applied Microbiology 21, 61-63.

Suzuki, H., Nishimura, Y., Yasuda, S., Nishimura, A., Yamada, M. \& Hirota, Y. (1978). Murein lipoprotein of Escherichia coli: a protein involved in the stabilisation of bacterial cell envelope. Molecular and General Genetics 167, 1-9.

WeIbull, C. (1953). The isolation of protoplasts from Bacillus megaterium by controlled treatment with lysozyme. Journal of Bacteriology 66, 688-695.

Weidel, W., Frank, H. \& Martin, H. H. (1960). The rigid layer of the cell wall of Escherichia coli strain B. Journal of General Microbiology 22, 158-166.

WestPHAL, O. \& JANN, K. (1965). Bacterial lipopolysaccharides. Extraction with phenol-water and further applications of the procedure. Methods in Carbohydrate Chemistry 5, 83-91.

Winter, A. J., KatZ, W. \& Martin, H. H. (1971). Murein (peptidoglycan) structure of Vibrio fetus comparison of a veneral and an intestinal strain. Biochimica et biophysica acta 244, 58-64.

Wright, B. E. \& Rebers, P. A. (1972). Procedure for determining heptose and hexose in lipopolysaccharides. Modification of the cysteine-sulphuric acid method. Analytical Biochemistry 49, 307-319.

YEM, D. W. \& WU, H. C. (1978). Physiological characterization of an Escherichia coli mutant altered in the structure of murein lipoprotein. Journal of Bacteriology 133, 1419-1426. 